\title{
Teaching for social impact: integrating generational goals and concerns into religious education
}

\author{
Kevin Sandberg ${ }^{1}$ (D) \\ Published online: 30 July 2020 \\ (c) Australian Catholic University 2020
}

\begin{abstract}
Claims of everyone a changemaker and calls for social and environmental responsibility resonate with today's young adults. Less religious than preceding generations, they tend instead to draw their values and purpose from consumer, cultural, and employment affinities. They also rely on their connectivity, digital or otherwise, for the ability to make an impact in the direction of social change they deem necessary. Yet they are less connected than previous generations to some of the most fundamental means that support change, especially faith, family, and institutional leadership. To have a hand in shaping their generational desire for change, religious educators can design curricula to achieve not just traditional student learning outcomes, but social impact outcomes, too. Toward this end, the article proposes that religious educators approach students of religious education as engaged practitioners of change on a contemporaneous basis as well as in anticipation of their future agency. Doing so would instantiate teaching for social impact as a particular form of the praxis already prevalent in religious education. The article explores this potential through a survey of the cause-concerns and desires of young adults in Australia and the United States; a conceptual analysis of the engaged practice that is grounded in studium, or the zeal for coherence; and a description of what it might look like for religious education to integrate social impact outcomes into curricular considerations on the basis of such studium.
\end{abstract}

Keywords Young adults $\cdot$ Engaged practice $\cdot$ Studium $\cdot$ Social impact $\cdot$ Praxis

\section{Introduction}

The Vatican hosted its first hackathon in March 2018. Though it sounds like computer security was being breached, VHacks, as it was known, was instead a social innovation pitch competition. Its goal was to recruit young adults to forge new tools of social inclusion and interfaith dialogue for the care of migrants and refugees-issues and a population close to the Pope's heart. One of the 120 university students to participate was Lucy Obus, an undergraduate studying communications, culture, and technology at Georgetown

Kevin Sandberg

ksandberg@nd.edu

1 University of Notre Dame, Notre Dame, IN, USA 
University in Washington, D.C. She described her experience as "a cool and impactful opportunity," noting "I learn best from experience and get frustrated doing a lot of talking (about stuff) but not doing (the stuff)" (Georgetown).

How can religious education address pedagogical and curricular preferences like those of Obus and her generation? Could it reshape aspects of itself so that, like VHacks, it might more completely harness the enthusiasm of a generation for a new ecology of change, one that manifests social as well as interior transformation? Religious educators are accustomed to turning to the concept of praxis when the nexus of theory and practice surfaces, as intimated by the distinction Obus makes between talking and doing. Recent trends in the social ecology of young adults confirm the value of praxis as a frame of reference for religious education. With this in mind, the article proposes a particular form of praxis for religious education, namely, one that teaches for social impact by approaching participants in religious education as engaged practitioners of change as well as subject-agents of personal transformation.

The first part of the article provides a sketch of young adults today. It inquires into a recent worldwide survey of 18 to 35 -year-olds, with a focus on findings from Australia and the United States, the first available country-specific data of the survey and the two countries for which the survey results are quite similar. The data include the cause-concerns of young adults but raise doubts about their capacity to achieve their goals. There are hopeful signs: young adults do exhibit a strong desire to have an impact. Nevertheless, though they appear to predicate their ability to have an impact on the basis of their connectivity, connectivity is only a necessary, not a sufficient element to bring about social change. Hence the second part of the article, which proposes that religious educators approach their students as engaged practitioners of change. Fundamental to this approach is a consideration of studium, or the zeal for coherence, as a metaphor by which religious educators can assess how well their pedagogical practices and spaces align with the connectivity, cause-concerns, and the desire for social change manifest by young adults today. The third part of the article envisions how religious educators can teach for social impact by integrating generational goals into their curricular considerations.

The article is not a theoretical treatment of the aims of religious education. Neither is it empirically based. Though the article takes up the topic of social impact, and on that basis touches upon social theories of religious education, it does not seek to interrogate communal, axiological, developmental, or transformational theories of religious education at either individual or social levels. Rather, following Biesta (2018) the article strives for the conceptual clarity that is a necessary first step before normative claims can be made at a theoretical level. Conceptual analysis plays an important heuristic role. When religious educators propose further clarity to the concepts central to their work, they ultimately provide their students greater facility to create and imagine their way to better possible worlds. For this reason, the present inquiry begins with the social reality that Obus and her generation inhabit, then proceeds methodologically by means of pragmatism. A reliance on pragmatism need not signal that the measure of education lies in its instrumental value. Rather, according to Kaushik and Walsh (2019) pragmatism considers existential contingencies to be fundamental rather than exceptional in nature. It affords experience pride of place. Moreover, it has a strong affinity for social justice orientations. Additionally, per Biesta (2015), pragmatism provides a philosophical tool that can be used to address a particular problem rather than meet the desire to build or critique an entire theoretical system. As the next section of the article demonstrates, the ability of young adults to deal with the cause-concerns that animate them presents religious education with a pressing problem. Religious education can redress this problem with its capacity to kindle, illumine, and 
guide social as well as interior transformation. At the same time, religious education itself can be reshaped by the process.

\section{The cause-concerns and desire of a generation}

A cause-concern is a conceptual amalgamation of the concerns that young adults have about the state of the world and the causes for which they advocate. A cause-concern can take the form of an existential uncertainty, as in the case of the coronavirus pandemic or climate change, where no immediate remedy is at hand. It can also take the shape of a social movement. This has been the case, for instance, with civil rights. Cause-concerns are not limited to issues of poverty, though they do encompass what would ordinarily fall within the category of social justice. As such, cause-concerns can be understood as embodiments of the demands for social change.

What are the cause-concerns of today's young adults? What worries them? Where do they want to see change? According to a recent survey by the Barna Group (2019), the top cause-concerns of young adults around the world are strikingly similar. The survey found the top five globally shared cause-concerns to be: (1) corruption, (2) climate change, (3) pollution, (4) extreme poverty, and (5) racism (see Table 1). Young adults in Australia hold the same top five concerns in common with the global results, but rank climate change ahead of corruption. Young adults in the United States hold three of the same top concerns in common with Australians, but rank corruption and racism ahead of climate change.

The reality underlying these results came to dominate headlines just a year later: In Australia, the bushfires were interpreted as a manifestation of global climate change; in the United States, the impeachment trial of the president illustrated concerns over abuse of power and economic inequality. The seeming correlation between these events and the young adult cause-concerns reported a year earlier is likely only symptomatic of the cultural patterns that have adversely affected the spirituality of young adults for decades. Rossiter (2018), for instance, has shown how the implied "spirituality" of consumerist cultures has rampantly supplanted religious spirituality. Though not focused on spirituality per se, the Barna data do indicate that young adults have fewer resources than preceding generations to address the causes that concern them. As a result, they appear to be situated

Table 1 Top 5 most pressing concerns facing the world's future according to young adults

\begin{tabular}{lll}
\hline Global & Australia & United States \\
\hline 1. Corruption & 1. Global climate change & 1. Corruption \\
2. Global climate change & 2. Corruption & 2. Racism \\
3. Pollution & 3. Pollution & 3. Global climate change \\
4. Extreme poverty & 4. Extreme poverty & 4. Healthcare \\
5. Racism & 5. Racism & 5. Education \\
\hline
\end{tabular}

Source Barna (2019, p. 34)

The survey, conducted online, including on mobile devices, between December 4, 2018 and February 15, 2019, represents 15,369 young adults worldwide, including 1,676 in Australia and 2,000 in the United States. Globally, the male to female ratio of respondents was $51 \%$ to $49 \%$. At the time of publication, the Barna data was not available on a disaggregated basis that might address differentials in race or ethnic background, socio-economic status, or educational achievement 
somewhere between enervated and invigorated when faced with the world's challenges. This is the case for at least three reasons: the state of their psychological well-being, the degree to which they engage faith and family, and the level of trust they place in institutional leadership.

\subsection{Many young adults are psychologically vulnerable}

According to Barna, one in five young adults worldwide feels less than capable of making important decisions, overcoming failure, wrestling themselves free of sadness or depression, and feeling secure in who they are (2019, p. 13). Yet, the percentage of young adults who feel unprepared for integration into the world jumps to one in three (i.e., to $33 \%$ from $20 \%$ when the findings for the U.S. and Australia are considered separately from the global results (ibid., p. 13). Feelings of vulnerability and uncertainty in young adults are often attributed to their developmental stage (Fowler 1981). They are part of the natural and necessary shift a young adult makes from dependence on external authority to reliance on inner resources. That transition, it has been observed, is best served by relationships that take on a mentoring function relative to the big questions and worthy dreams that arise in the hearts and minds of young adults (Parks 2000). Over the past twenty years, though, young adults have come of age in an era in which even the best of mentoring is overwhelmed by the terrorist attacks of 9/11, the Great Recession of 2008, and the ubiquitous smart phone. Turkle (2011) describes how the latter influence portends an increasingly invasive digitized future, one that has rendered us "alone together." As a result, today's young adults lack much of the privacy and security in which earlier generations were raised, educated, and employed. "Though they are physically safer, they are psychologically more vulnerable" (Barna 2018, pp. 15-16).

\subsection{Fewer young adults rely on faith and family}

One reason why young adults might feel unready to face the world is that they lean less on faith and family than preceding generations. Globally, little more than half of young adults see the church as important to society or good for people, though among Christian respondents these figures rise to about three-quarters (Barna 2019, p. 23). Earlier research reveals that only one-third of Generation $\mathrm{Z}$ describes family as central to their identity, a decrease from preceding generations (Barna 2018, p. 13). It is no surprise, then, that twice as many GenZers do not identify with any faith tradition as compared to their parents-13\% as compared to $6 \%$ (ibid., p. 14). Young adults who do practice religious faith demonstrate the strongest levels of "connectivity": they feel cared for, show concern for the world, and have a forward-looking disposition (Barna 2019, pp. 14-15). Yet, even where the experience of church does connect young adults to one another, fewer than $50 \%$ in both Australia and the U.S. cite a church's community involvement as a reason for belonging (ibid., p. 29). Moreover, only $41 \%$ of young adults in Australia and $40 \%$ in the U.S. consider care for the poor and the vulnerable to be central to Christian identity (ibid., p. 25). These results are not surprising given cultural ambivalence about religion and the prevailing dropout rates from religion- $71 \%$ in Australia and $64 \%$ in the U.S. (ibid., p. 22). The results are troubling, though, if one of religious education's roles is to include young adults in creating social change now, not just preparing them to do so later in life. 


\subsection{Young adults place less trust in institutional leadership}

Perhaps the starkest of the survey's findings is that young adults have little confidence that leaders with institutional authority can fix society's problems. The majority of young adults agreed strongly or somewhat strongly (84\% in Australia, $85 \%$ in the U.S.) with the statement that "society is facing a crisis in leadership because there are not enough good leaders right now" (Barna 2019, pp. 32-33). Not surprisingly then, Barna reports (ibid., pp. 12-13) that more young adults feel anxious and uncertain about the future $(50 \%$ in Australia, $49 \%$ in the U.S.) than feel optimistic about it (37\% in Australia, 39\% in the U.S.). Significantly, this leadership crisis includes the sense among young adults that they themselves lack the ability to lead. They feel too busy, distracted, and apathetic to assume leadership roles. Only $10 \%$ of Australian and $15 \%$ of U.S. young adults consider themselves leaders in either social causes/nonprofits or church/faith communities, combined (ibid., p. 36). Yet, they also cite exclusion from opportunities and changing expectations as reasons that inhibit their own development in leadership roles.

\subsection{Young adults desire to make an impact}

If young adults do exhibit disconcerting degrees of psychological vulnerability, decreased reliance on faith and family, and diminished expectations of leadership, how then do they plan to forge a future commensurate with their life goals? In a word, together. With mobile phones in hand, they create social networks to address their cause-concerns. Much like the methodology of the Vatican hackathon, young adults engage problems increasingly on the basis of their connectivity - be it electronic, interpersonal, or otherwise. So connected is this generation that their propensity to be digitally connected to one another and the consistency of the survey findings across the globe led Barna (2019) to dub today's 18 to 35-year-olds the "connected generation".

The drive for social change that is present among young adults is correlated with their propensity for connectivity. This drive is evident in the prevalence of the term "social impact". Witness the high school student who says, "My biggest goal is to go to college and continue to impact the communities that have impacted me" (Stein 2020). To attract students who desire to have such an impact, Australian Catholic University, for instance, has relied on the marketing slogan "It's your future. Make an impact" (ACU). Philanthropies and nonprofit organizations use the language of impact to similar effect. Donors to a nonprofit enterprise, for instance, have typically received an acknowledgement letter for tax purposes. Today they also typically receive an impact report that is designed to show that the nonprofit is effectively fulfilling its mission, that it produces outcomes that match its goals. Consider the following statement from an actual impact report: "Your impact changes the future for more than 14,000 moms, dads, brothers and sisters..." (Common Hope). This statement exalts the donor for the influence they have in the sphere of their cause-concern. Note that it is no act of flattery for a nonprofit to regard a donor as a person of influence. Though nonprofits live and die by philanthropy, they are no sycophants. Rather, nonprofits and philanthropic organizations have adopted the language of impact not only to signal that change is happening, but also to identify the donor as the agent of that change.

This is precisely how young adults want to be regarded-as agents of change. In their lexicon, social impact is a new term for social justice, one that avoids connotations of the 
judgmentalism they disparage. Moreover, their use of "impact" demonstrates the degree to which they perceive making an impact to be a social experience, not just one of individual agency. No one person-whether wealthy philanthropist, a sustaining donor, or a novice giver-effects change on their own. The era of networking demonstrates that the sum, in this case, change, is greater than the parts. For instance, online crowdfunding mechanisms often afford participants the opportunity to draw others in to shape projects collaboratively. Platforms like GoFundMe, Kickstarter, and Giving Tuesday enable and inspire people to raise, donate, and invest money in the presence of others who share their cause-concern. Though this collaboration takes place online, what is nevertheless operative in it is the social nature of human agency. As one fundraising professional describes the phenomenon, "It is inherently a community activity even if it's just you and your credit card and the internet when you do it. You're doing it in this social context" (Wallace 2017).

In sum, as the connected generation relies on social networking to tackle their cause-concerns, they are reshaping the social ecology of change. For many young adults, this new ecology of change is replacing more traditional routes to social change, including nonprofits and religious organizations. Yet, no small number of young adults lacks the confident, forward-looking disposition on which both interior and social change are predicated. That disposition is often derived from connections to faith and family, such that the survey reports a troubling finding: For every young adult who feels deeply cared for (only one in three), an equal number of young adults feel lonely and isolated (Barna 2019, pp. 8-9). To the extent that faith and family have been supplanted, at least in part, by social networking, a corresponding loss in the critical lens and intergenerational solidarity that religious education typically affords young adults augurs poorly for their ability to make an impact.

\section{Educating engaged practitioners of change}

If a new ecology of social change is taking shape by which young adults plan to make an impact, then religious education might ask itself how it fits in this ecology of change. Do young adults perceive social impact as constitutive of religious education? Do they at least perceive religious education as propaedeutic to the ability to make an impact, as ACU's marketing invites them to do? To address these questions, this section of the article explores a framework by which religious education could educate young adults as engaged practitioners of change. Such a framework, which is praxis in nature, could provide religious education a means by which to work with the connected generation's cause-concerns in the context of their affinity for networking and their desire for social impact.

Central to the framework for educating engaged practitioners of change is the notion of studium. Studium connotes the zeal that underlies that act of studying and the space, like a studio, in which one studies-studium being the Latin root of study and studio. As such, studium provides a metaphor to catalyze a discussion on the ways in which religious education practices align pedagogical address with pedagogical sites. Pedagogical address and pedagogical site are terms that Di Leo and Jacobs (2004) employ to bring pedagogical considerations into closer relation with the actual contexts in which learning takes place. They argue that "pedagogical theory premised upon the classroom as a fixed entity is no longer acceptable. We must learn how to adjust our pedagogy to account for the changing nature of the classroom" (2004, p. 10). Religious educators, Harris (1989) and Foster (1994) for instance, have long recognized that the teaching-learning which constitutes religious education precedes and transcends formal classroom and school-based contexts. In particular, 
religious education attends to settings of family, congregations, and communities as primary educational contexts. As it is presented here, studium provides religious education yet another basis to counter biases that remain against what are perceived to be non-traditional forms and sites of learning. From the standpoint of religious education, that which takes place outside a classroom is not inferior educationally. Participants in religious education should not be presumed to be enrolled in an institutional schooling setting.

\subsection{Praxis in religious education}

As an instance of praxis in religious education, the general shape of what engaged practice looks like can be seen in the remarks that Obus, the Georgetown undergraduate, made about the Vatican hackathon. As noted earlier, Obus calls VHacks a "cool and impactful opportunity." Coupled with "cool," her use of the word "impactful" could signal that by "opportunity" she is referring to her own education. However, when impact is considered linguistically, as noted above, it is clear that Obus could also be speaking about the opportunity to make an impact for the benefit of migrant and refugee populations. Her more extensive comments about VHacks support this interpretation. There, she sees impact arising from "Georgetown's commitment to social justice" (Georgetown). In other words, VHacks demonstrates to Obus the coherence of Georgetown's Catholicity-that it puts its faith into action.

To be sure, social justice is not exclusively a religious preserve. Yet it is characteristically Jesuit. Its presence in Georgetown's educational ethos is influenced by the Jesuit decree of 1975 that the "promotion of justice" is essential to all their ministries (see Padberg 2009). That decree followed upon the teaching of Vatican II and in particular the postconciliar synodal declaration in Justice in the World that "action on behalf of justice and participation in the transformation of the world fully appear to us as a constitutive dimension of the preaching of the Gospel" (Synod 1971, par. 6). In this view-one which Obus appears to hold - faith and action are constitutive parts of an integral whole. Ultimately, they are only perceived as separable from one another when an analytical point of view has been assumed. Scholars of religious education refer to the integrity of this whole under the aegis of praxis. Praxis has been adopted by and adapted for religious education especially as it counters tendencies in either religious or educational settings to focus on interior dispositions alone, whether spiritual or cognitive, or social activism alone, unmoored as it can become from critical reflection. For this reason, Fleischer emphasizes that the praxis approach to religious education has helped to shift "religious sensibilities away from a contemplative mode that shuns worldly action to an integrative mode that acts reflectively in the world..." (2000, p. 208).

The integrative mode to which Fleischer points is perhaps the most prominent aspect of praxis as discussed by religious educators. It is the feature that Imbelli and Groome (1992), for instance, highlight when they describe praxis as the twofold process whereby theory interprets practice, even going so far as to illuminate its implications, while practice surfaces, tests, and critiques theory, especially by probing its embedded assumptions. Theory and practice are attached in an essential way; their functionality is dependent on one another. Yet, an overreliance on thumbnail sketches like "reflective action" and "informed practice" to characterize praxis can miss what lies at its heart, namely, the drive to discover, act out of, and act toward coherence. Coherence is the condition in which analytically separable elements, like faith and action or reflection and practice, are understood to exhibit a certain logical consistency between themselves. It is with this condition in mind 
that religious education seeks the embodied unity of faith and action, reflection and practice. Thus, it is not principally the cyclical, rhythmic, or dialectical movement from theory to practice and back again that characterizes praxis. Rather, praxis is the drive to manifest the coherence of elements that, though they constitute an embodied whole, become abstracted from one another too readily. At the heart of praxis, then, is a rejection of the bifurcation and consequent hierarchy of (Western) rationality in which theory has too often been prioritized over practice.

For their part, religious educators have not failed to redress the privileged position granted to thought over action, to theory over practice; hence their turn to praxis. This corrective is what Eugene (1990) refers to when he describes "action-reflection" as the result of a paradigmatic shift in religious education away from "reflection-action" sequencing. The shift does not suggest that action is pursued heedless of thought but prioritizes considerations of context (action) over content (reflection). Action-reflection sequencing also counters educational tendencies to prioritize abstract thinking over embodied thinking. "Action-reflection learning is a relational, reflective, and experiential way of knowing in which by critical reflection on lived experience people discover and name their own story and vision and, in a Christian education context, the story and vision of the faith community" (Eugene 1990, p. 2). Groome (1991) provides a paradigmatic instance of this with his shared Christian praxis approach to religious education. Yet Groome goes further than the paradigm shift to action-reflection sequencing suggests (where for Groome "action" is an engagement with present reality or how one is acting or instantiated in the world). The integrative functionality of praxis, he notes, ought to be understood today to include, in contradistinction to Aristotle's view, not just active and reflective modes but creative modes of being, too, or what Moore (1991) describes as the imaginative mode.

\subsection{Religious education for engaged practice}

Praxis, then, is a way toward ensuring the integrity of embodiment - a way that seeks and holds as a unified whole the modes of doing/acting and talking/knowing for the sake of creating fruitfulness. It stitches together active and reflective processes that might otherwise go their separate ways. It pushes the diachronic tendencies of reflection (traditioning from generation to generation) to encounter the synchronic tendencies of action (engaging the immediacy of life), and vice versa. The encounter of the two modes sparks the creative mode that fulfills the coherence necessary for embodiment. One instantiation of such active-reflective creation toward embodiment can be found in what is being called here engaged practice. Engaged practice is reflection-in-action rather than reflection-on-action. The prepositional difference shifts the timing of reflection to take place in the immediacy of the moment, rather than after the fact of action. Though both dynamics are parts of the whole that is praxis, reflection-in-action directly serves creative purposes while reflectionon-action directly serves thought. Service learning is an instance of the latter. Students use journal entries, group discussions, and mentor debriefing to reflect after the fact of providing some service for which they have been prepared in advance. With reflection-in-action, reflection no longer takes past experience as its object. Instead, reflection-in-action is what could be called colloquially "thinking on your feet". It is the result of the deep learning that undergirds the phronesis, or prudential judgment or practical wisdom, toward which praxis is intended. Reflection-in-action emphasizes the creative, decisive adjudication that takes place in the real time of engaged practice. This adjudication concerns the differential that 
exists between the actual circumstances that practitioners face in the field and the model circumstances in which they were trained beforehand as learners.

Schön calls this differential the "indeterminate zones of practice" (1987, p. 6). Indeterminate zones of practice are constituted by the vagaries and exigencies of everyday life that require decisive action in the moment and on the spot, rather than ponderous consideration after the fact. Professionals like architects, counselors, designers, engineers, planners, musicians, etc., exhibit a strong capacity to not only work, but also to thrive in the indeterminate zones of practice, according to Schön. When the pre-established goals, parameters, and tools in which professionals are educated fail to account for the unique, uncertain, and unfamiliar circumstances they encounter, professionals are able to transcend the prior constructions of knowledge in which they were trained. Doing so enables them to redefine problems in ways that render solutions more possible.

Though Schön calls those who successfully navigate indeterminate zones of practice "reflective practitioners," what is operative seems no longer to be reflection at all. In fact, Schön attributes reflection-in-action to a more fundamental capacity, one he calls artistry. In artistry, he includes wisdom, talent, and intuition. Artistry, according to Eisner, results from an ability to inhabit the "vacillation between playing and gaming, between algorithms and heuristics, between structure-seeking and rule-abiding behavior" (2002, p. 162). Such an aptitude is critical to the construction of new ways of thinking. In other words, artistry means that solutions are not pulled out of a static storehouse of knowledge, as if problems are categorical and pre-defined. It entails, instead, processes by which practitioners redefine the understanding of what the problem is in the first place. In doing so, professionals experience regular renewal in the underlying purpose to which they have "engaged" themselves.

Considered etymologically, the word "engaged" means to commit, pledge, or bind oneself ("engage" 2020). Practitioners initially engage, or bind themselves to, a community of practice on the basis of their formal education. Palmer (1993) observes that to acquire knowledge a learner makes a commitment to a particular subject matter and, in general, forsakes most other areas of study. Expertise is also dependent on participation in a community of practice, not just a subject area. Professional practitioners are bound to the community of practice through accreditation, oaths, and codes of conduct. Moreover, the community at large has a role to play in sustaining the community of practice. Indeed, to the degree that wisdom, talent, and intuition arise from practice in indeterminate zones, it can be said that a practitioner's artistry accrues to them more on the basis of relationships within the communities they serve than on the basis of professional associations. It is not on the basis of such relationships or through such relationships, but in the midst of them, as with a doctor-patient or lawyer-client relationship, that engaged practitioners adjudicate on a real-time basis the mismatch between prior constructions of knowledge and the myriad, evolving particularities of life meant to be aided by that knowledge.

In addition to binding themselves to a field of knowledge and to a community of practice, there is a third way in which practitioners are engaged in the etymological sense of the word. In a particularly religious way, they are bound to act thermostatically relative to the exigencies of the situations in which their practice places them. To be thermostatic means that a practitioner is bound to a new condition, value, or norm, one that may yet be discovered, but is nevertheless discoverable or able to be constructed. The metaphor is based on a thermostat's function to change the temperature. That functionality renders a thermometer a "positive" instrument; it merely reports the temperature independent of any value assessment. A thermostat, on the other hand, is normative in nature. It assesses the thermometer's objective measurement relative to a preset norm. If there is a differential, 
the thermostat makes the adjustments necessary to bring about the new norm. In other words, it makes an impact.

Martin Luther King Jr. demonstrates what it means for religion to be thermostatic in his Letter from Birmingham Jail. The letter is a classic piece of literature in the demonstration of the coherence of faith and action. It articulates how the veracity of Christian doctrine is measured by its moral and social implications. Writing to the clergy who judged the civil rights marches in Birmingham, Alabama, to be, as they put it, "unwise and untimely", King (1963) argues that the ancient church was not a "thermometer that recorded the ideas and principles of popular opinion; it was a thermostat that transformed the mores of society." So, too, should religious education be thermostatic. The church, as King demonstrates, has historically been thermostatic. To be engaged, then, is not just a synchronic affair. As King demonstrates, to be engaged one must also be diachronically so. The practitioner is responsible through time to millennia of religious practice as well as to the exigencies of the situation at hand.

By developing the thermostatic nature of faith in a student, engaged practice situates structural transformation, or social change, at the center of religious identity. Postman (1979) argues that education, too, functions thermostatically. It provides counterarguments to norms, practices, and principles that threaten to become hegemonic. Religious education calls on its practitioners-learners and teachers alike - to be thermostatic in both diachronic and synchronic ways. This pertains to the commitments that are fundamental to religious education: commitments to fields of knowledge, communities of practice, and human and social exigencies as well as tradition. To act thermostatically means to discover and enhance the coherence implicit to these commitments and the ecology by which they remain bound to one another. The ability to pursue, disclose, and act relative to such coherence is what engaged practice develops in a practitioner.

\subsection{Practice grounded in studium}

One way that religious education can bring about the coherence King demands of Christian faith is by turning to the metaphor of studium. Studium can be used to measure the degrees to which the pedagogical addresses and sites employed in religious education meet human and social exigencies. As noted previously, studium is the Latin etymological source of the verb to study and the nouns that designate places of study, namely, a study or a studio. It means "earnest application, enthusiasm, eagerness" ("study" 2020). In the context of religious education, studium represents the disposition that seeks faith's coherence. It is zeal for coherence. It is what Obus manifests in her reaction to the Vatican hackathon. What she saw in VHacks was a coherent faith-one that demonstrated the Jesuit charism for the faith that does justice. Studium is not limited to the academic pursuit of knowledge. It is, rather, a fundamentally human and potentially social characteristic that drives the person or community to seek coherence, embodiment and impact. It is the wellspring of engaged practice's thermostatic nature. As such, studium can serve as an organizing principle for the engaged practice that seeks to unleash the thermostatic nature of faith in students of religious education.

The metaphorical potential of studium is derived from the physical and functional characteristics of what a studio is ordinarily considered to be- a space dedicated to creative art forms, like painting, music and film, or the training of the body for particular forms of movement, as with dance or yoga studios. In contrast to labs (which facilitate experimentation), lecture halls (which distribute information), and classrooms (which perfect 
reasoning), a studio provides space for non-linear, extra-cognitive faculties to shape the human response to life's exigencies, be they social or individual. As such, studio practice has the potential to guide practitioners through the creative, reflective, and active modes of praxis that bring questions and cause-concerns to a point of coherence. In the move toward coherence, studio engagement surfaces, refines, and manifests the deepest understandings of intent, meaning, and purpose that motivate a practitioner.

In a studio, a practitioner's studium is moved to coherence through creative interaction with the studium of other members of the community of practice. The dynamic between different studium can be likened to a potter working with clay in a ceramic studio. Since clay is a composite of particles it is said to have its own ideas; it cannot be formed into just any desired shape. Until they can be brought to cohere with the nature of the clay, the potter's intentions for the clay are only tentative and aspirational. A master practitioner in clay notes that "the better we understand the underlying structure the more closely [the clay] can be adapted to our needs. The right clay used in the right way can be a faithful servant, but the wrong clay and the wrong use turns it into an exacting tyrant" (Norton 1975/1976, p. 12). Studium works analogously. The community of practice assembled in studio draws out from one another and works collaboratively with each other's studium. Each participant in the community of practice presents themselves in studio as a differentiated life such that a multimodal network of studium develops in the process.

The common reference point for the creativity that results from a studio is an artform, such as ceramic after a piece of clay has been thrown on a pottery wheel. Confidence in this creativity, Kelley and Kelley (2013) have argued, has been "educated" out of most people at a young age. Somewhere and at some point, someone communicated to them that they were not creative, for instance, because they were not good at drawing. To overcome the intimidation that the challenge to create often poses, novices are guided in studio experience by a master practitioner. A master practitioner, or maestro, does not try to bring a practitioner's craft to perfection, for the point is coherence. Rather, the maestro brings at least two fundamental questions to bear: What studium surfaces as members of the community of practice interact with one another relative to the situation of concern? And, does the community of practice recognize that the concern as presented is an adequate representation of reality, or does the surfaced studium help to redefine reality more adequately? Just as a potter negotiates their intent for the clay with the clay's own properties, so too the maestro leads a collaborative interplay of inquiry by asking, showing, imagining, forming and reshaping. It is with such a dynamic in mind that Moran has described religious education as the "shaping of life's forms with end and without end" (1989, p. 49).

As a physical environment for work, a studio provides space to promote the creative and imaginative processes from which emerge innovations and inventions in thinking, collaboration and doing. It is for reasons such as these that the contemporary work environment is increasingly being designed in the fashion of a studio space. This is particularly evident with corporate settings like those of Apple and Google. In a bid to enhance the collaboration and heuristic thinking that brings possibilities to the surface and experiments with them, fixed office space is giving way to open floor concepts, flexible furniture arrangements, and the presence of recreational equipment in the workplace. The same can be said of trends in the renovation of housing. The open and flexible space common in residential housing today functions to unite families that have disparate schedules and diverse interests. To adopt into religious education the functionality of such workspace and residential configurations would provide for what Eisner refers to as expressive activity: the desired outcomes result from intentionally planned activities that do not have a pre-determined outcome other than to "provide a fertile field for personal purposing and experience" (2002, p. 
119). The function promoted by a focus on studium is heuristically similar: in the exchange of possibilities among the multiple participants in a community of practice, purpose is surfaced; as purpose is surfaced, problems can be redefined. In short, studio serves to reshape prior understanding into possible reality.

\section{Teaching for social impact}

The intent of the preceding section was not to propose studium as pedagogical theory. Rather, studium and the potential it presents to integrate social impact more thoroughly within the aims of religious education is a response to the zeal evident among Obus and her generational cohort. Young adults want to participate in reshaping society; they need not eagerly await that role. Religious education as an engaged practitioner can provide them a framework to do so in the present moment as well as in the future. True to the praxis approach to religious education, this framework keeps their action and reflection cohering with one another toward a social and interior transformation that is no less integral. It is toward such a vision of integrity that it has been argued of Christianity, to cite one religious tradition, that it "insists upon an inherent connection between personal transformation and social change" (Regan 2002, p. 99). The social impact toward which studium is directed is neither the fullness nor the sole aim of religious education. Rather, religious education seeks to form, inform and transform people of all ages for a life in which the interior and exterior cohere with each other in the context of religious tradition(s). Indeed, insofar as studium propels social impact, it presupposes the metanoia and practices-personal and communal-that are characteristic of religious tradition(s), including especially prophetic aspects. With its characteristic sensibility for praxis, religious education educates the whole person (ontologically, hermeneutically and axiologically as well as cognitively, affectively and behaviorally) for the whole of reality (spatially and temporally) across the whole of life (diachronically and synchronically). Its telos is the embodiment of activereflective creation. Its heuristic exercises form the fulcrum by which self and world are moved in response to the transcendence invited forth by the potential for a transfigured and fruitful life. That transcendence includes social impact outcomes-social embodiments of transfigured life that manifest metanoia toward the common good.

\subsection{Social impact outcomes}

A social impact outcome (SIO) is a conceptual amalgamation of "social impact" and "outcomes". The notion stands in analogy to the student learning outcomes (SLO) with which school-based educators are long familiar. Student learning outcomes are statements of the observable and measurable effect of educational exchanges, lessons, assignments, courses, curricula, degrees, etc. (Eisner 2002). They encapsulate the aims of education, i.e., what a community values and the benefits of those values. By their nature, outcomes are something to be assessed. They do not exist independent of the set of values against which they are to be measured. The question of outcomes forces the community to ask whether their attainment turns human existence toward or away from greater degrees of flourishing. Just as SLOs are crafted relative to learners (e.g., "at the end of this course, students will be able to..."), so too social impact outcomes (SIO) are designed relative to the members of society being engaged in an educational endeavor (e.g., "at the end of this project, patrons of the St. Vincent de Paul food bank will..."). By their nature, though, it is tempting to 
think that an SIO would be as profound as something like "at the end of this course, hunger will decrease by $x$ number of percentage points." Yet, few would expect religious education to have as its direct objective the reduction of hunger. Nevertheless, there is a "content" aspect to an SIO just as there is a content to an SLO; it is the impact to be achieved.

As noted earlier, the fervor of young adult life for such social impact is something already kindled, illumined and guided by religious tradition(s). Nevertheless, Roebben (2019) presses religious educators to provide young adults with new wineskins, for they themselves and the present moment constitute new wine-what has been described heretofore as the cause-concerns and studium of the connected generation. A "soft correlative adaptation of old forms of tradition to the contemporary situation," he states plainly, will not suffice (2019, p. 53). Including social impact outcomes as a curricular embodiment of studium is one possible new wineskin. Studio-like spaces and their associated practices provide a form for the new wine that is each generation's studium. They increasingly shape the work world into which young adults are graduating from formal schooling. Paying attention to these spaces helps ensure that religious education allows itself to be in praxis relationship with culture, community, and society, including congregational and church life. To remain engaged with that everchanging reality, Di Leo and Jacobs (2004) urge that forms of pedagogical address and pedagogical sites regularly undergo assessment and potentially, reconfiguration in any of three interrelated ways: spatially, since space and place have to be recognized to afford educational possibilities and potentials; pedagogically, since there is an inherent interaction between the space in which teaching-learning occurs and the humans effort to educate; and politically, since no classroom is hermetically sealed off from, but is in dialogue with the institutions that characterize the wider culture, community and society.

\subsection{Social impact outcomes in practice}

As an example of how studio might work in religious education, consider again how religious educators might interact, where appropriate, with concern about the food deserts of impoverished communities. One reason for religious education to do so would be to take a cue from Obus and the connected generation: they are eager to "make an impact", as the ACU puts it. Indeed, many who do have a religious faith understand this faith as coherent only when it leads to impact. Their studium finds its resonance when it witnesses faith being done rather than only discussed. They are looking for more than the inclusion of poverty or justice concerns in their curriculum. Their faith seeks its coherence in corporal reality. Toward this end, a religious educator might align a traditional SLO (e.g., "students will learn the significance of the exhortation to feed the poor to the Christian message") with an SIO (e.g., "residents of the neighborhood will report a reduction in concerns over food security"). To be sure, outcomes are expectations. Moreover, no one individual or group may impose their will or studium on another. Yet, what could occur might look like math students meeting school district officials who present data on free lunches; from that conversation, a studium could surface in the examination of numbers that reveal socio-economic inequalities. Students interested in psychology might then interview mothers who depend on a local food pantry; they could share the community member's studium as they write narrate local poverty. Students who want to study medicine might then examine the nutritional value of a food pantry diet; the studium of hungry kids would likely surface as they examine the long-term consequences of health disparities. 
Each of these learning groups forms a node in a developing network that has the potential to redefine a presenting social problem. It might become evident, for instance, that a food desert develops gradually as a result of economic change, just as the topography of land can gradually turn to desert due to climate change. The studio participants might ask why a school does not have its own food pantry if a church is expected to have one. Though the problem of a food desert might not be resolved, the understanding of the problem can be redefined. In the process of being redefined, a network that can lead to a solution is formed. In this way, an engaged practice built on studium enables students to become practitioners of change in the immediacy of their own lives. It practices them to function beyond the networks of texts, rules and guidelines that, in their perception, typify religion and education. Doing so begins to educate students as engaged practitioners of change. As Schön describes practitioners:

They are in transaction with their practice worlds, framing the problems that arise in practice situations and shaping the situations to fit the frames, framing their roles and constructing practice situations to make their role-frames operational. They have, in short, a particular, professional way of seeing their world and a way of constructing and maintaining the world as they see it (1987, p. 36).

The network that comes into being around a reliance on studium bears some semblance to the networking on which the connected generation has predicated the hope of a better future. When built with the aid of studium as metaphor, education for engaged practice can surface deep purpose and drive that purpose to its point of coherence. It can foster the creative mastery to tackle the cause-concerns that applied knowledge fails to solve. Intractable problems do not require new solutions. They require, instead, different pedagogical, cognitive and relational constructs that have the power to redefine problems. This is why Pope Francis argues in Laudato $\mathrm{Si}^{\prime}$ that the world cannot solve its environmental problems by means of the same technical rationality, or technocratic paradigm, that caused the problems in the first place. By fostering engaged practice on the basis of studium - the purpose, the zeal, even the faith with which people hold and pursue their cause-concerns-religious education provides a means to achieve the social impact both called for in its traditional learning goals and yearned after by the connected generation.

\subsection{A curricular consideration}

Though religious educators might blanch at the idea of solving world hunger as an educational objective, if hunger is going to be remediated, then it makes sense that religious education would make some contribution to the solution. That contribution would include forming interior dispositions of empathy and compassion, crafting analytical lenses to understand the dynamics of the situation in which one finds the self to be observer/participant, and reflecting theologically on the demands of religious tradition/faith to participate in the divine mystery becoming apparent. But could not religious educators also entertain the possibility of a decrease in inner-city food deserts, for example, as an SIO to accompany the exhortation to feed the hungry, an SLO found in numerous religious traditions? To be sure, motivation is difficult, if not impossible, to assess. With regard to religious precepts about feeding the hungry, though, motivation is not the point. The point is the impact of hunger being abated.

Social impact outcomes can be considered learning outcomes designed with a student's cause-concern in mind. They enable students to experience agency relative to educational 
programming as well as their cause-concerns. As the possibility of impact is increased in collaborative and educational contexts, the social aspect of agency becomes increasingly apparent to students. Indeed, it may be that what an SIO looks like depends less on a religious tradition's teaching than on the social vector for change that becomes available to it when young adults network, including in schooling contexts. As a result, SIOs need not be completely pre-formulated, as typically takes place with behavioral and problem-solving objectives in educational design. Rather, they can be the product of the congress, facilitated by a studio exchange, of students with local social systems.

It is in their practice of problem-defining rather than problem-solving that Schön's reflective practitioners provide a curricular model for the education of engaged practitioners of change. Recall that cause-concerns are intractable problems-what even the Australian government has called "wicked problems" after Rittel and Webber (1973) because they are "highly resistant to resolution" (Australian Public Service Commission). Ought young adults to wait until they are fully educated before they tackle their cause-concerns? By addressing young adults as already engaged practitioners of change, religious education prioritizes doing the work called for over reflective exercises that are not at the same time creative embodiments of the impact demanded by thermostatic faith. Without a thermostatic religious education centered on doing as well as talking (to use Obus' terms), there remains a question as to why religious education, in the Christian context for instance, might expect the gospel to effect the social change it demands (Carr 1986). Toton concurs: "It is only in acting that our analysis is sharpened, that the gospel becomes alive in our lives, and that the struggle for justice moves forward" (1985, p. 458). To address the everchanging nexus of spatial, pedagogical and political considerations, religious educators can begin to consider ways in which social impact outcomes can be created to align with traditional student learning outcomes and the aims of religious education.

\section{Conclusion}

Animated by the notion of studium, religious education can educate engaged practitioners of change. Doing so has the potential to surface for young adults the zeal that drives faith to its point of coherence. This includes social change alongside interior transformation. Though young adults seldom lack the zeal to address their uncertainties and cause-concerns, they often lack a sophisticated theory of change, a set of practices and a comprehensive network by which to effect impact. Yet, as the comments on "doing" from Obus suggest, many young adults want no small part of their educational experience to include these resources. Religious education does need the "talk" that is entailed in critical reflection and theoretical contemplation. Yet its students also need experiences of impact and agency that draw their studium to its point of coherence. To benefit the connected generation's studium, religious education might increasingly teach with social impact in mind by integrating generational goals and cause-concerns into its curricula. Doing so could include the space and functionality that arise in studios, which increasingly populate the contemporary work world. Why not populate religious education with such spaces, too, where the school is not prototypical, but space is meaningful?

The portrait painted of the connected generation is one of young adults for whom purpose and connectivity are paramount. Is religious education providing new wineskins that are sufficient to hold their wine, their studium? The data reveal that a significant portion of young adults is experiencing disruptions to some of the most fundamental 
forms of connectivity, namely, the human ones. As the Barna study indicates, these disrupted connections include connections to leaders, who disappoint their hopes for the future; connections to faith and family, which today form less of a young adult's identity; and even connections to the self, which suffers reduced confidence. Nevertheless, as Obus demonstrates, in their educational lives as much as through their eventual professional lives, young adults manifest a desire to have an impact on their cause-concerns. The marketplace, including Catholic schools like ACU, knows this about young adults and responds accordingly. Increasingly, young adults demonstrate their drive to social change through their purchasing power as well as through community involvement and philanthropic activity. They ally themselves to product brands and will boycott companies that adopt positions or affiliate with politicians who are anathema to them. They approach their purchases as investments in social change. Through their social networks they influence their friends to do the same.

But do they see religious education similarly disposed? They might see Pope Francis, especially in light of Laudato $\mathrm{Si}^{\prime}$, as sympathetic to environmental causes. But do the schools and churches and agencies in their neighborhoods and communities appear to them to be sufficiently thermostatic relative to the cause-concerns that preoccupy their generation? How many young adults would speak of their religious education, in whatever form, in terms similar to those Obus used to describe VHacks-a cool and impactful opportunity? How many might make similar comments if their experience of religious education were, first and foremost, a demonstration of the practical import of faith? If religious education is concerned with the lives of young adults—and it sincerely is - then it could do no worse than to follow their lead in becoming more concerned with generating impact. Yes, as McKinney has argued in his analysis of the link between Catholic social teaching and Catholic schools, religious education must prepare young people "to take up their rightful place in the world and transform the world through Christian love and social justice” (2019, p. 402). But religious education can also teach for social impact in ways that move beyond the merely propaedeutic.

Given the connected generation's desire for impact, religious educators have before them the opportunity to rethink how they can prepare young adults for future social change at the same time that they engage them in present social change. Absent inclusion of this generation's goals and cause-concerns in its curricula, religious education runs the risk that the connected generation will drop religious education from its social network. If they do so, and the data show that at least two-thirds of the connected generation already does, young adults will have likely concluded that they do not rank very high in the network that constitutes religious education.

\section{Author contributions Self alone.}

Funding This research received no external funding.

Data availability Not applicable.

Code availability Not applicable.

\section{Compliance with ethical standards}

Conflicts of interest The author declares that there is no conflict of interest. 


\section{References}

ACU (n.d.). Australian Catholic University. Retrieved January 2020, from https://www.acu.edu.au/.

Australian Public Service Commission (2018). Tackling wicked problems: A public policy perspective. Archived document. Retrieved May 11, 2020, from https://www.apsc.gov.au/tackling-wicked-probl ems-public-policy-perspective.

Barna. (2019). The connected generation: How Christian leaders around the world can strengthen faith \& well-being among 18-35-year-olds (Australia/New Zealand Report \& United States Report, each with the same pagination). Barna Group ebooks.

Barna. (2018). Gen Z: The culture, beliefs and motivations shaping the next generation. Barna Group ebooks.

Biesta, G. (2018). Creating spaces for learning or making room for education? New parameters for the architecture of education. In H. Tse, H. Daniels, A. Stables, \& S. Cox (Eds.), Designing buildings for the future of schooling: Contemporary visions for education (pp. 27-39). New York: Routledge.

Biesta, G. (2015). Pragmatism and the philosophical foundations of mixed methods research1. In A. Tashakkori \& C. Teddlie (Eds.), SAGE Handbook of mixed methods in social \& behavioral research (pp. 95-118). Thousand Oaks, CA: SAGE Publications Inc.

Carr, N. (1986). The social impact of Christian theology and pedagogy: A plea for change. Journal of Christian Education, 86, 19-32.

Common Hope (2018). https://www.commonhope.org/get-to-know-us/our-impact/. Donor impact report (online version). Retrieved May 12, 2020, from https://www.commonhope.org/wp-content/uploa ds/2020/02/2018-Common-Hope-Donor-Impact-Report-Online-Version.pdf.

Di Leo, J., \& Jacobs, W. (2004). Place, Pedagogy, Politics: Reflections on Contemporary Classroom Configurations. If classrooms matter: Progressive visions of educational environments (pp. 1-14). New York: Routledge.

Eisner, E. W. (2002). The educational imagination: On the design and evaluation of school programs (3rd ed.). Upper Saddle River, New Jersey: Merrill Prentice Hall.

Engage (2020). OED Online. Oxford University Press. Retrieved May 12, 2020, from https://www.oed.com/ view/Entry/62192?rskey=uhe8Te\&result=3\&isAdvanced $=$ false.

Eugene, T. (1990). Action-reflection. In I. Cully \& K. Cully (Eds.), Harper's encyclopedia of religious education (pp. 1-2). New York: Harper \& Row.

Fleischer, B. (2000). A theological method for adult education rooted in the works of Tracy and Lonergan. Religious Education, 95(1), 23-37.

Foster, C. (1994). Educating congregations: The future of Christian Education. Nashville, TN: Abingdon Press.

Fowler, J. (1981). Stages of faith: The psychology of human development and the quest for meaning. San Francisco: Harper \& Row.

Georgetown (n.d.). Coding for the Vatican: CCTer Lucy Obus was part of the winning Georgetown team that competed at the first ever VHacks. News article. Georgetown University. Retrieved from https:// cct.georgetown.edu/news-story/coding-for-the-vatican/.

Groome, T. (1991). Sharing faith: A comprehensive approach to religious education and pastoral ministry: The way of shared praxis. Eugene, Oregon: Wipf and Stock Publishers.

Harris, M. (1989). Fashion me a people: Curriculum and the church. Louisville: Westminster John Knox Press.

Imbelli, R., \& Groome, T. (1992). Signposts towards a pastoral theology. Theological Studies, 53, 127-137.

Kelley, D., \& Kelley, T. (2013). Creative confidence: unleashing the creative potential within us all. New York: Crown Business.

King, M. (1963). Letter from Birmingham Jail. Archived document. Retrieved from https://kinginstitute. stanford.edu/king-papers/documents/letter-birmingham-jail.

McKinney, S. (2019). Catholic social teaching, Catholic education and religious education. In M. Buchanan \& A.-M. Gellel (Eds.), Global perspectives on Catholic religious education in schools (pp. 393-403). Singapore: Springer.

Moran, G. (1989). Religious education as a second language. Birmingham, Ala.: Religious Education Press.

Norton, F. H. (1975/76). Clay: Why it acts the way it does. Studio Potter, 4(2), 10-12. Retrieved June 18, 2020, from https://www.studiopotter.org/articles/art0019.htm.

Padberg, J., Ed. (2009). Decree 4: Our mission today: The service of faith and the promotion of justice (General Congregation 32). Institute of Jesuit Sources. Archived document. Retrieved May 12, 2020, from https://jesuitportal.bc.edu/research/documents/1975_decree4gc32/.

Palmer, P. (1993). To know as we are known: Education as a spiritual journey. San Francisco: HarperSanFrancisco. 
Parks, S. D. (2000). Big questions, worthy dreams: Mentoring emerging adults in their search for meaning, purpose, and faith. San Francisco: Jossey-Bass.

Postman, N. (1979). Teaching as a conserving activity. New York: Delacorte.

Kaushik, V., \& Walsh, C. (2019). Pragmatism as a research paradigm and its implications for social work research. Social Sciences, 8(9), 255.

Regan, J. (2002). Toward an adult church: A vision of faith formation. Chicago: Loyola Press.

Rittel, H., \& Webber, W. (1973). Dilemmas in a general theory of planning. Policy Sciences, 4(2), 155-169.

Roebben, B. (2019). New wine in fresh wineskins: Rethinking the theologicity of Catholic religious education. In M. Buchanan \& A.-M. Gellel (Eds.), Global perspectives on Catholic religious education in schools learning and leading in a pluralist world (Vol. 2, pp. 51-61). Singapore: Springer Nature.

Rossiter, G. (2018). Life to the full: The changing landscape of contemporary spirituality-implications for Catholic school religious education. Sydney: ASMRE.

Schön, D. (1987). Educating the reflective practitioner: Toward a new design for teaching and learning in the professions. San Francisco: Jossey-Bass.

Stein, P. (January 3, 2020). A rising star who aims to elevate others. The Washington Post. Retrieved from https://advance-lexis-com.proxy.library.nd.edu/api/document?collection=news\&id=urn:contentIte m:5XWP-6SH1-DXXY-336R-00000-00\&context=1516831.

Study (2020). OED Online. Oxford University Press. Retrieved April 17, 2020, from https://www.oed.com/ view/Entry/192083.

Synod of Bishops. (1971). Justice in the World. In D. O'Brien \& T. Shannon (Eds.), (2010), Catholic social thought: The documentary heritage (pp. 288-300). Maryknoll, N.Y.: Orbis.

Toton, S. (1985). Structural change: The next step in justice education. Religious Education, 80(3), 447-459.

Turkle, S. (2011). Alone together: Why we expect more from technology and less from each other. New York: Basic Books.

Wallace, N. (2017). Why innovation matters: with big change looming in giving, nonprofits must experiment-and challenge their assumptions. In The Chronicle of Philanthropy (January). Retrieved from https://bi.gale.com.proxy.library.nd.edu/essentials/article/GALE\%7CA485989198/3e86fabd53323ef db6a3df034e85a55e?u=nd_ref.

Publisher's Note Springer Nature remains neutral with regard to jurisdictional claims in published maps and institutional affiliations.

Kevin Sandberg is assistant teaching professor at the University of Notre Dame (USA), where he directs discernment initiatives in the Center for University Advising. He is an ordained priest of the Congregation of Holy Cross. 